\title{
Usulan Peningkatan Kapasitas dengan Meningkatkan Kinerja Lini Produksi Melalui Model Simulasi (Studi Kasus di PT X, Bekasi)
}

\section{Capacity Improvement by Improving Production Line Performance Through Simulation Model (Case Study at PT X, Bekasi)}

\author{
Kirana Hapsari, Victor Suhandi \\ Program Studi Teknik Industri, Fakultas Teknik, Universitas Kristen Maranatha, Bandung \\ E-Mail : kiranahappsari@gmail.com, victorsuhandi@yahoo.com
}

\begin{abstract}
Abstrak
PT X adalah perusahaan manufaktur yang bergerak di bidang otomotif kendaraan komersial. Perusahaan ini memproduksi truck dengan model $N$-Series dan F-Series. Cabin pada model FSeries lebih besar dibandingkan $N$-Series. Permasalahan yang terjadi adalah kapasitas produksi departemen paint shop tidak mencapai target.Departemen paint shop hanya mencapai output sebesar 40 unit $N$-Series per shift dan 9 unit F-Series per shift, padahaloutput yang diinginkan perusahaan sebesar 43 unit $N$-Series per shift dan 11 unit F-Series per shift. Departemen paint shop memiliki 34 proses produksi untuk masing-masing model cabin. Satu stasiun kerja dengan stasiun kerja lainnya saling berkaitan untuk mencapai output perusahaan. Metode penyelesaian masalah menggunakan simulasi komputer, karena ketergantungan antar variabel sistem yang sangat kompleks. Pembuatan model simulasi awal dengan pemeriksaan program komputer sesuai dengan spesifikasi yang diinginkan. Model simulasi dijalankan untuk dievaluasi dan dianalisis hingga hasil simulasi awal mencapai 40 unit $\mathrm{N}$-Series per shift dan 9 unit F-Series per shift. Kemudian akan dilakukan eksperimen pada model usulan dengan penentuan alternatif tindakan berdasarkan variabel keputusan pada influence diagram, seperti perubahan waktu proses, perubahan jumlah operator, perubahan daya tampung, jumlah mesin yang akan digunakan, hingga penugasan operator. Hasil simulasi usulan mencapai 43 unit $N$-Series per shift dan 11 unit F-Series per shift. Hal tersebut telah sesuai dengan target yang perusahaan inginkan.
\end{abstract}

Kata Kunci: Simulasi, Influence Diagram, Kapasitas Produksi.

\begin{abstract}
$P T X$ is a manufacturing company that producing automotive commercial vehicles. This company manufactures trucks with type of $N$-Series and F-Series. Cabin F-Series bigger than $N$-Series. The problem is the target of paint shop department production capacity are not achieve. Paint shop department only achieve 40 unit per shift $N$-Series and 9 unit F-Series per shift, whereas the desired output the company by 43 unit per shift $N$-Series and 11 unit FSeries per shift. Paint shop department has 34 production process for both type of cabin, and every work station has interrelated. The method of problem solving is by using computer simulation, because of the complexity of systems variables dependencies. We makes the existing simulation modelby examination the computer simulation model elements. The simulation model is run repeatedly to be evaluated and analysed to achieve an output of 40 unit per shift $\mathrm{N}$-Series and 9 unit F-Series per shift. And then, we perform simulation experiments on the decisions variables, such as the time changes, changes in the number of operators, changes in capacity, the number of machines that will be used, until the operator assignments. The result of proposed simulation has reached 43 unit per shift $N$-Series and 11 unit F-Series per shift. So, the company's target is accomplished.
\end{abstract}

Keywords: Simulation, Influence Diagram, Production Capacity. 


\section{Pendahuluan}

Studi simulasi bermanfaat untuk memodelkan masalah yang kompleks. Lini produksi memiliki banyak faktor produksi dan hubungannya yang kompleks sehingga permasalahan ini dapat dipandang sebagai masalah yang kompleks. Papadopoulos (2009) menyebutkan simulasi lini produksi merupakan sarana yang sangat ampuh untuk dapat memperoleh ukuran kinerja dimana metode analitik akan sulit bahkan tidak dapat digunakan. Di dalamnya terdapat model umum untuk lini produksi yang digambarkan memiliki beberapa stasiun kerja, dan di setiap stasiun kerja memiliki sejumlah mesin paralel, kemudian di antara stasiun kerja terdapat buffer. Komposisi lini produksi seperti demikian akan memunculkan permasalahan keseimbangan beban kerja, pengalokasian server, dan pengalokasian buffer. Heshmat (2013) menyampaikan studi simulasi diterapkan untuk mengukur kinerja lini produksi dengan cara menganalisisnya dan mencari bottleneck yang ada sehingga permasalahan-permasalahan tersebut muncul ketika menganalisis lini produksi.

Ukuran kinerja dari lini produksi dapat berupa (Papadopoulos, 2009):

- Throughput

- Utilisasi setiap work-station

- Rata-rata tingkat buffer

- Rata-rata work-in-process

- Rata-rata waktu menunggu pekerjaan

Simulasi menjadi sarana yang sangat populer untuk memecahkan permasalahan lini produksi. Heshmat (2013) mengamati lini produksi semen, Khalafi (2014) menunjukkan betapa efektifnya simulasi dalam menganalisis bottlenecks pada lini produksi industrial valve, Saidabad (2015) meneliti peningkatan laju produksi peleburan baja yang dipengaruhi faktor eksternal dan internal yang menggambarkan faktor-faktor yang tidak dapat dikendalikan dan yang sebaliknya. Hasil penelitiannya merekomendasikan hal-hal detil yang dapat dihasilkan dari studi simulasi seperti mengatur waktu makan dan membuat penyimpanan di antara stasiun kerja. Wirabhuana (2008) meminimasi ketidakseimbangan beban kerja lini perakitan truk dengan membandingkan efisiensi lini perakitan awal dengan empat lini perakitan usulan. Hafezalkotob (2014) menunjukkan permasalahan ketidakseimbangan lini produksi pipa dengan cara mengidentifikasi bottlenecks kemudian dengan simulasi dapat memberikan pemahaman untuk melakukan perbaikan seperti perubahan lokasi dan secara tepat merekomendasikan peningkatan kinerja di suatu stasiun kerja.

Studi simulasi dinilai sangat mampu untuk memecahkan permasalahan lini produksi terkait peningkatan kapasitas. Peningkatan kapasitas ini dapat melalui analisis utilisasi yang kemudian dilanjutkan dengan penentuan bottlenecks. Hasil yang diharapkan adalah dapat melakukan perbaikan yang sangat spesifik terkait kapasitas lokasi atau sumber daya tertentu, dan terus berkelanjutan seperti siklus hingga mencapai kapasitas yang diinginkan. Perbaikan dapat berupa peningkatan kapasitas secara langsung ataupun perubahan cara kerja sehingga beban kerja antar stasiun menjadi lebih seimbang.

PT X merupakan industri manufaktur yang bergerak di bidang otomotif kendaraan komersial. Perusahaan ini memproduksi dua jenis truck dengan model $\mathrm{N}$-Series dan $\mathrm{F}$-Series, dimana ukuran cabin $F$-Series lebih besar dibandingkan $N$-Series. Proses pengecatan merupakan salah satu prosesnya. Berdasarkan pengamatan dan wawancara yang telah dilakukan, kapasitas produksi pada departemen paint shop masih perlu ditingkatkan, karena output yang dihasilkan hanya mencapai 40 unit $N$-Series per shift dan 9 unit $F$-Series per shift. Padahal target output yang diinginkan perusahaan adalah 43 unit $N$-Series per shift dan 11 unit $F$-Series per shift. Penyebab dari permasalahan tersebut adalah pengerjaan painting truck untuk model $\mathrm{N}$-Series dan $\mathrm{F}$-Series pada proses paint shop disatukan dalam satu jalur yang sama, dengan waktu proses pengerjaan yang berbeda untuk masing-masing model cabin. Sehingga hal tersebut menyebabkan terjadinya blocking pada saat proses produksi berlangsung. Selain itu, kualitas cabin yang dihasilkan pada setiap proses produksi tidak sesuai dengan target perusahaan, yang menyebabkan proses 
penanggulangan defect diakhir proses painting lama. Dengan tingginya waktu proses dibeberapa stasiun kerja, maka kapasitas produksi dapat menurun karena proses produksi melebihi waktu siklus yang telah ditetapkan perusahaan.

Batasan yang digunakan dalam penelitian ini adalah objek penelitian hanya membahas proses produksi paint shop, penelitian menggunakan data waktu proses produksi paint shop untuk model cabin $\mathrm{N}$-Series dan $\mathrm{F}$-Series, periode pengukuran waktu operasi dilakukan dari tanggal 1 September 2014 sampai dengan 30 September 2014 dengan jam kerja normal, yaitu 8 jam kerja efektif, dan ukuran kinerja simulasi diukur dari jumlah output yang dihasilkan oleh model simulasi tersebut. Sedangkan asumsi yang digunakan adalah tidak ada pergantian operator pada saat dilakukan penelitian dan jumlah alat material handling cabin yaitu dolly selalu mencukupi.

Tujuan dilakukannya penelitian ini adalah memberikan usulan jadwal urutan pengerjaan cabin truckN-Series dan F-Series pada stasiun kerja pertama departemen paint shop dan memberikan usulan kapasitas terkait sumber daya dalam lini untuk mencapai output yang diinginkan pada proses produksi paint shop.

Proses produksi painting cabin dikerjakan pada satu jalur yang sama, dengan waktu proses untuk model $N$-Series dan $F$-Series berbeda. Painting cabin ini dilakukan 34 proses untuk masing-masing model cabin, dimana proses satu dan lainnya berkaitan untuk menghasilkan kapasitas produksi. Dikarenakan ketergantungan satu variabel dengan variabel lainnya yang sangat kompleks, digunakan model simulasi menggunakan software ProModel untuk menghasilkan peningkatan kapasitas produksi paint shop. Simulasi didefinisikan sebagai sekumpulan metode dan aplikasi untuk menirukan atau merepresentasikan perilaku dari suatu sistem nyata, yang biasanya dilakukan pada komputer dengan menggunakan perangkat lunak tertentu (Law, 1991). Wawasan mengenai perilaku sistem sebenanrnya didapatkan dengan mempelajari kebiasaan dari model (Harrel, 2003). Melalui model tersebut, pembuat simulasi pun dapat menganalisis untuk memahami kondisi suatu sistem. Pembuatan simulasi ini agar dapat mewakili proses paint shop, sehingga dapat menghemat biaya dan waktu dibandingkan pengaturan langsung di pabrik yang beresiko besar apabila terjadi kegagalan, serta tidak akan menghambat proses produksi cabin yang sedang berlangsung.

Penentuan alternatif tindakan yang akan dilakukan dengan menggunakan influence diagram. Influence diagram adalah salah satu cara yang tepat untuk menggambarkan sistem secara garis besar guna menggali informasi dalam konteks hubungan struktural (structural relationship) dan hubungan sebab-akibat (causal relationship) antar komponen-komponen sistem (Daellenbach, 1994). Pada penelitian ini, influence diagram digunakan untuk mempertimbangkan faktor-faktor yang mempengaruhi seluruh performansi sistem, sehingga dapat mengetahui variabel keputusan yang akan diterapkan pada model simulasi usulan, agar kapasitas produksi departemen paint shop sesuai dengan target yang diinginkan perusahaan.

Diagram alir dari pengolahan data yang akan dilakukan ditunjukkan pada Gambar 1. Adapun keterangan langkah-langkah dari diagram alir pengolahan data tersebut adalah:

1. Membangun Model

Langkah awal untuk membangun simulasi yaitu dengan membuat layout berdasarkan lantai produksi paint shop di PT X. Susunan mesin dan ukuran layout juga sesuai dengan kondisi aktual PT X. Layout ini akan digunakan sebagai background pada model simulasi. Gambar 2 menunjukkan layout proses produksi paint shop. Setelah layout dibuat, langkah selanjutnya adalah pembuatan lokasi. Lokasi dibuat untuk tempat operasi yang dilakukan entity (input) berupa cabin $N$-Series dan F-Series. Lokasi ini dinyatakan dalam rupa gambar seperti mesin-mesin, stasiun kerja, WIP, antrian, dan sebagainya yang menggambarkan lokasi pada paint shop. Kemudian penentuan entitas yang merupakan input yang akan mengalami proses yaitu cabin $\mathrm{N}$-Series dan $\mathrm{F}$ Series. Selanjutnya pembuatan blok processing sebagai operasi yang terjadi di dalam sistem dan perpindahan entitas antar lokasi. Tahap membangun model pun perlu memperhatikan arrivals yang menyatakan kedatangan entity pertama kali pada suatu sistem yang akan diamati. Penentuan waktu warm-up period pun sangat penting untuk model simulasi nonterminating. Penentuan waktu warmup period dilakukan dengan menjalankan model selama 22 jam dengan interval length selama 1 
JOURNAL OF INTEGRATED SYSTEM VOL 1. NO. 1, JUNI 2018: 1-19

jam, sehingga menghasilkan output data sebanyak 22 periode. Replikasi dilakukan 1 kali, karena input data yang digunakan (yaitu waktu proses pengerjaan cabin) bersifat deterministik. Output data 22 periode $N$-Series akan dihitung menggunakan metode welch moving average untuk melihat kondisi steady state model. Nilai $w$ (moving average window) yang digunakan dalam perhitungan welch moving average yaitu 6 . Semakin ditingkatkan nilai $w$ maka semakin meningkat pula "kehalusan" dari moving average plot.

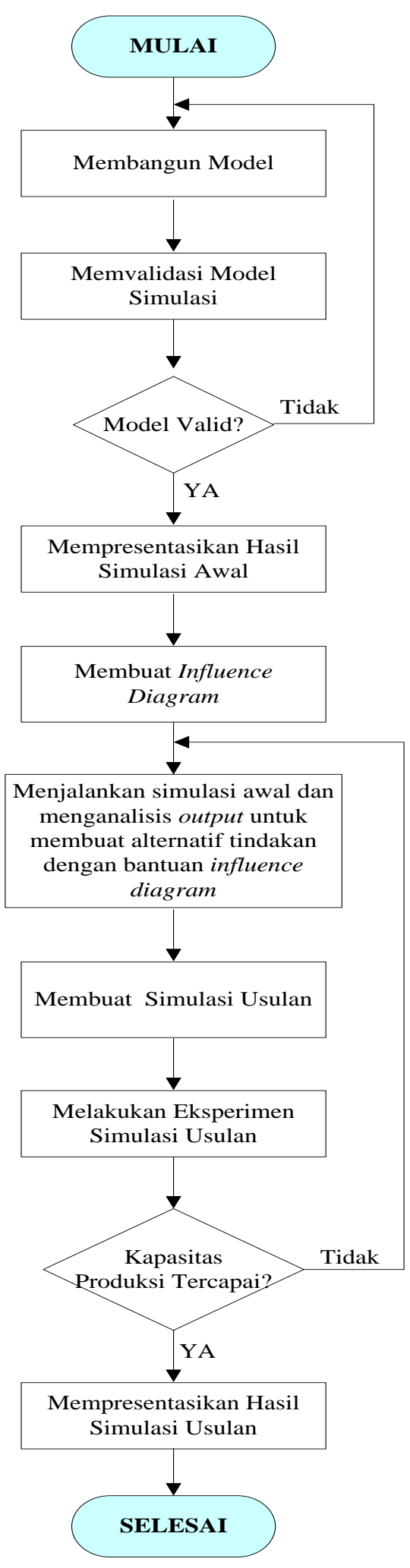

Gambar 1. Diagram Alir Pengolahan Data 
PENINGKATAN KAPASITAS DENGAN MENINGKATKAN KINERJA LINI (Kirana H., dkk.)

2. Memvalidasi Model Simulasi

Model simulasi yang dibangun harus kredibel. Representasi kredibel sistem nyata oleh model simulasi ditunjukkan oleh verifikasi dan validasi model. Pada tahap ini dilakukan validasi internal dan validasi eksternal terhadap model simulasi. Validasi internal biasa disebut dengan tahap verifikasi. Verifikasi adalah pemeriksaan apakah program komputer simulasi berjalan sesuai dengan yang diinginkan, melalui pemeriksaan program komputer. Verifikasi memeriksa penerjemahan model simulasi konseptual (diagram alur dan asumsi) ke dalam bahasa pemrograman secara benar (Law, 1991).

Validasi eksternal merupakan tahap validasi model, yaitu penentuan apakah model konseptual simulasi adalah representasi akurat dari sistem nyatanya (Law, 1991). Pada penelitian ini, model simulasi dijalankan berulang kali untuk dievaluasi dan dianalisis, apakah hasil yang didapatkan sudah mencapai target yang diinginkan perusahaan pada bulan September 2014, yaitu 40 unit $\mathrm{N}$ Series per shift dan 9 unit F-Series per shift. Apabila model sudah mencapai target perusahaan, maka dapat dikatakan model valid. 


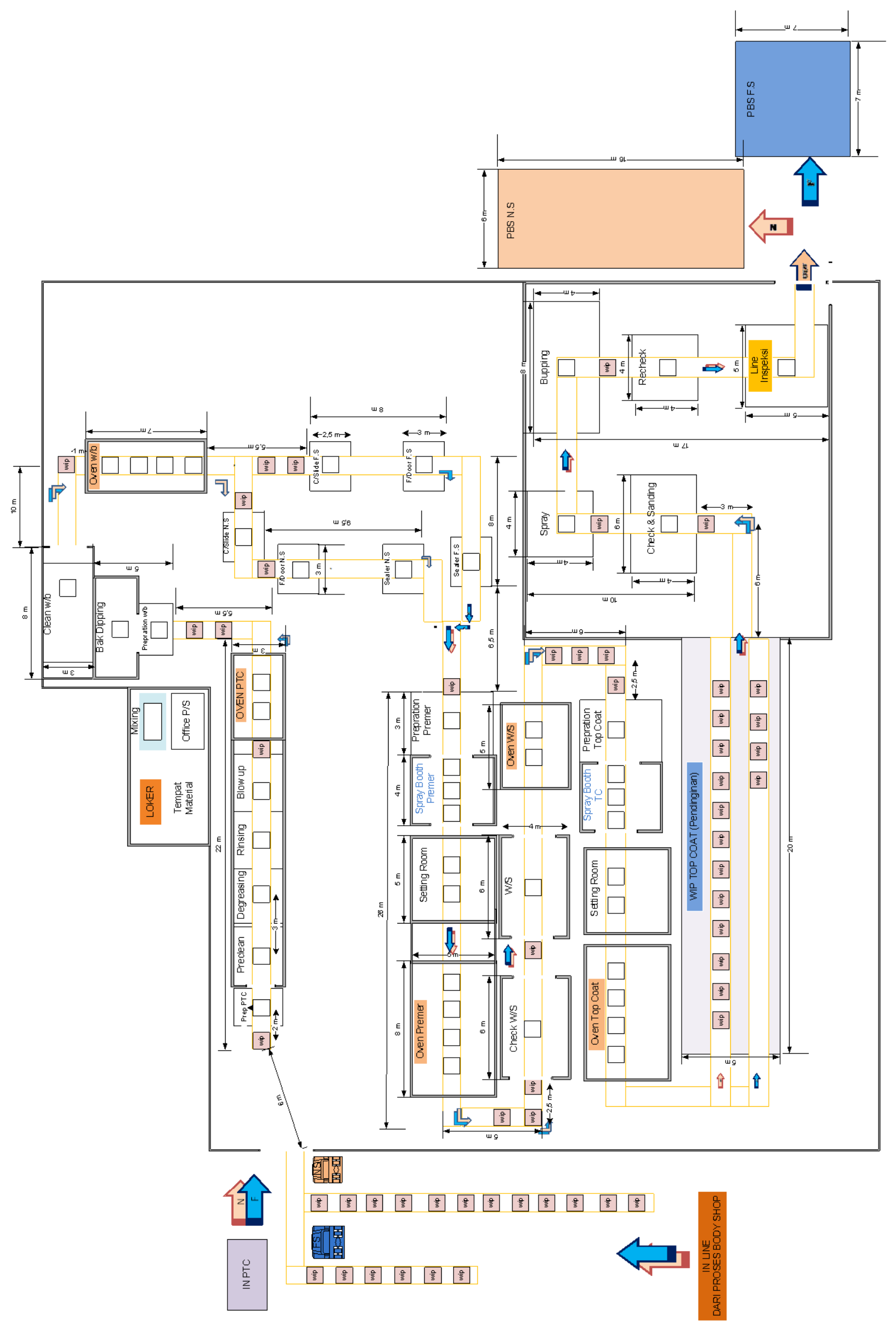

Gambar 2. Layout Produksi Paint Shop 
3. Mempresentasikan Hasil Simulasi Awal

Menyampaikan hasil yang yang didapat dari model simulasi dan memberikan keputusan dari hasil tersebut. Dalam hal ini melihat output yang dihasilkan dari hasil simulasi sesuai dengan produksi aktual atau tidak, yaitu 40 unit $\mathrm{N}$-Series per shift dan 9 unit $\mathrm{F}$-Series per shift. Bila telah sesuai maka model dapat digunakan karena sudah lolos dari tahap uji verifikasi dan validasi model.

\section{Membuat Influence Diagram}

Influence diagram digunakan untuk menggambarkan suatu pendekatan sistem yang menunjukkan ketergantungan satu variabel dengan variabel lainnya, sehingga mengetahui seluruh faktor-faktor yang dapat mempengaruhi performansi proses paint shop terhadap peningkatan kapasitas produksi. Dengan membuat influence diagram, dapat mengetahui variabel keputusan untuk mengambil alternatif tindakan yang akan diterapkan pada pembuatan simulasi usulan hingga mencapai kapasitas produksi sesuai dengan target perusahaan yang diinginkan.

\section{Membuat Simulasi Usulan}

Pada tahap sebelumnya didapatkan pencapaian output dari sistem aktual perusahaan. Kemudian dilakukan ulang pembuatan model simulasi setelah model simulasi awal sudah valid dengan menerapkan warm-up period.

\section{Melakukan Eksperimen Simulasi Usulan}

Selanjutnya menjalankan model simulasi usulan dengan menganalisis output yang dihasilkan pada model simulasi, kemudian dikaitkan dengan influence diagram untuk melihat variabel keputusan yang ingin digunakan sebagai alternatif tindakan untuk diterapkan pada model simulasi. Proses tersebut dilakukan berulang untuk setiap skenario yang ada, kemudian dievaluasi dan dianalisis hingga model dapat mencapai output yang diinginkan perusahaan sebanyak 43 unit $\mathrm{N}$-Series per shift dan 11 unit F-Series per shift.

7. Mempresentasikan Hasil Simulasi Usulan

Menyampaikan hasil yang yang didapat dari model simulasi usulan dan memberikan keputusan dari hasil tersebut. Dalam hal ini melihat output yang dihasilkan oleh simulasi usulan, hingga mencapai 43 unit $N$-Series per shiftdan 11 unit F-Series per shift.

\section{Pembuatan Model Simulasi Awal dan Usulan}

Terdapat berbagai macam data masukan untuk dianalisis lebih lanjut. Data-data tersebut dibedakan menjadi dua macam, yaitu data primer dan data sekunder. Data primer yang digunakan dalam penelitian ini didapatkan dengan melakukan wawancara kepada pihak yang berkepentingan pada proses paint shop yaitu, data hasil produksi untuk cabin $N$-Series dan $F$-Series pada proses paint shop dalam satu shift Bulan September 2014, dan kondisi pabrik yang sedang berlangsung. Data sekunder meliputi data umum perusahaan, data waktu proses pengerjaan cabin $\mathrm{N}$-Series dan $\mathrm{F}$ Series pada Bulan September 2014, layout pabrik paint shop, serta jenis dan jumlah mesin yang diggunakan.

Setelah data yang dibutuhkan untuk mendukung penelitiaan terkumpul, maka dibuatlah model simulasi. Model simulasi yang digunakan untuk penerapaan kasus perusahaan adalah simulasi nonterminating, dimana penganalisaan dilakukan pada suatu sistem yang berada pada kondisi steady state. Nonterminating simulation tidak berarti bahwa simulasi dijalankan tidak pernah berakhir, namun berarti bahwa simulasi dapat terus berlanjut tanpa batas dengan tidak ada perubahan statistik dalam perilaku sistem. Langkah awal untuk membangun model pada software simulasi yaitu membuat layout untuk penempatan lokasi, membuat entitas, penentuan arrival, proses operasi dan sebagainya sampai dengan simulasi berjalan. Model simulasi dijalankan beberapa kali untuk dievaluasi dan dianalisis hingga mencapai hasil output sesuai dengan yang perusahaan dapatkan. 


\subsection{Simulasi Awal}

Setelah model simulasi selesai dibuat, maka berikutnya merupakan tahap menjalankan model dengan menggunakan periode warm-up. Model dijalankan selama 22 jam dengan interval length selama 1 jam, sehingga menghasilkan output data sebanyak 22 periode. Replikasi dilakukan 1 kali karena data bersifat deterministik.

Perhitungan periode warm-up menggunakan metode welch moving average, dengan nilai $\mathrm{m}$ (periode output $)=22$ periode yang disesuaikan dengan periode hari kerja pada departemen paint shop. Sedangkan, nilai $w$ (moving average window) $=6$, karena menurut Law (1991) bahwa nilai $w$ tidak lebih dari $\mathrm{m} / 4$. Nilai $w$ ini ditingkatkan sebesar $20 \%$ dengan tujuan meningkatkan "kehalusan" dari hasil plot pada perhitungan moving average. Hasil dari perhitungan ini didapatkan 12 periode warm-up untuk mencapai kestabilan model. Kemudian, model simulasi dijalankan beberapa kali untuk dievaluasi dan dianalisis hingga mencapai hasil outputyang sesuai dengan perusahaan dapatkan. Tabel 1 menunjukkan hasil output(dapat dilihat dari kolom total exit) dari menjalankan simulasi awal adalah sebagai berikut:

Tabel 1. Output Simulasi Awal

\begin{tabular}{|c|c|c|c|c|c|}
\hline Name & Total Exits & Gurrent Qty In System & Avg Time In System (MIN) & Avg Time In Move Logic (MIN) & Avg Time Waiting (MIN) \\
\hline Cabin NS atas & 40,00 & 30,00 & 572,70 & 18,21 & 157,64 \\
\hline Cabin FS atas & 9,00 & 7,00 & 605,12 & 21,50 & 124,38 \\
\hline
\end{tabular}

Simulasi awal menghasilkan output sebesar 40 unit $N$-Series per shift dan 9 unit F-Series per shift. Output simulasi sudah sesuai dengan kapasitas produksi aktual perusahaan, sehingga dapat dikatakan model simulasi yang dibuat valid.

\subsection{Influence Diagram}

Influence diagram menggambarkan suatu pendekatan sistem yang menunjukkan ketergantungan satu variabel dengan variabel lainnya, sehingga mengetahui faktor-faktor yang dapat mempengaruhi performansi paint shop, untuk menghasilkan kapasitas produksi yang perusahaan inginkan. Pembuatan influence diagram ini berdasarkan seluruh proses yang terjadi pada departemen paint shop. Terdapat 4 simbol utama yang digunakan pada influence diagram ini. Lingkaran merupakan variabel sistem yang menghubungkan input dengan output. Awan menggambarkan input data dari lingkungan sistem yang tidak ingin dikontrol. Sedangkan persegi panjang menunjukkan variabel keputusan, dimana simbol ini merupakan aspek permasalaha yang ingin dikendalikan. Terakhir terdapat simbol oval yang menggambarkan output sistematau ukuran kinerja sistem. Pemberian warna pada influence diagrammenunjukkan bagian-bagian proses pada paint shop.Warna kuning menunjukkan proses inti paint shop, warna biru menunjukkan proses preparation, dan warna hijau menunjukkan proses pengovenan, touch up, serta area setting room. Gambar 3 menunjukkan influence diagram untuk mencapai kapasitas produksi yang diinginkan perusahaan pada departemen paint shop: 


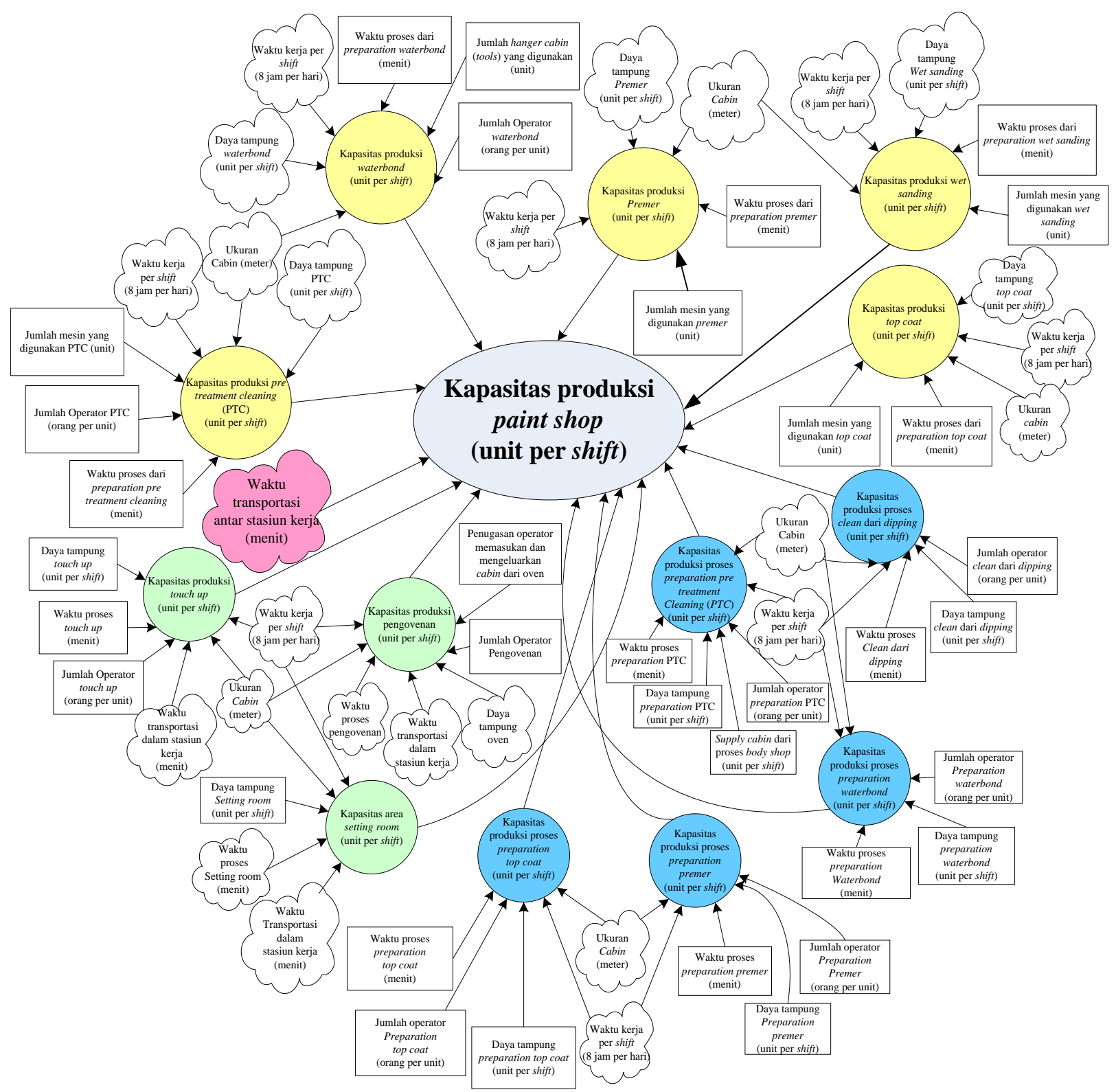

Gambar 3. Influence Diagram Departemen Paint Shop

Influence diagramdi atas menunjukkan apabila variabel output (oval) ingin dicapai, tidak hanya dengan control input (persegi panjang) saja, namun uncontrollable input (awan) pun ikut berperan. Satu stasiun kerja memiliki keterkaitan dengan yang lain, misalnya untuk menjamin kapasitas produksi pre treatment cleaning (PTC) terdapat faktor-faktor yang dapat mempengaruhi kapasitas produksi PTC, diantaranya jumlah operator yang mengerjakan proses PTC, jumlah mesin dan tools yang digunakan, waktu penyelesaian cabin sebelum proses PTC yaitu preparation PTC, daya tampung pada stasiun kerja PTC, ukuran cabin untuk model $N$-Series dan $F$-Series, sampai dengan waktu kerja per shift. Kompleksitas sistem dapat dilihat dari saling ketergantungannya antar variabel satu dengan variabel lainnya. Semua faktor-faktor tersebut sangat penting dalam pencapaian kapasitas produksi PTC, yang akan dijadikan input untuk mencapai target perusahaansebesar 43 unit $N$-Series per shiftdan 11 unit $F$-Series per shift.

\subsection{Analisis Hasil Output Simulasi Awal}

Simulasi awal menunjukkan output sebesar 40 unit $\mathrm{N}$-Series per shiftdan9 unit $\mathrm{F}$-Series per shift (dapat dilihat pada tabel 1 kolom total exit). Perusahaan menginginkan kapasitas produksi sebesar 
43 unit $\mathrm{N}$-Series per shiftdan 11 unit F-Series per shift. Oleh karena itu, dengan menganalisis output pada simulasi awal, terdapat operator yang bekerja sangat sibuk pada beberapa stasiun kerja. Gambar 4 menunjukkan grafik tingkat kesibukan operator dari hasil simulasi awal:

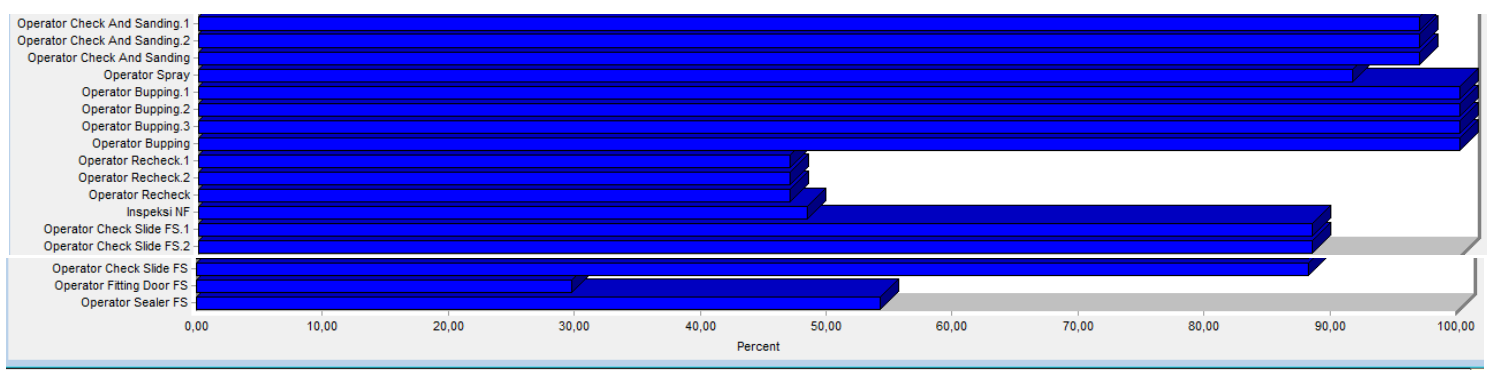

Gambar 4. Tingkat Kesibukan Operator pada Simulasi Awal

Dari grafik diatas, operator bupping memiliki tingkat kesibukan sebesar 100\%, check and sanding $96,81 \%$, dan spray $91,54 \%$. Proses tersebut merupakan proses touch up pada paint shop.

\subsection{Simulasi Usulan}

\subsubsection{Usulan Penerapan Jadwal Pengerjaan Cabin}

Proses paint shop merupakan proses perakitan truck tahap ke- 2 setelah proses perakitan body shop. Pada paint shop ini dilakukan paintingcabin model $N$-Series dan F-Series, dimana untuk mengerjakan painting ini membutuhkan output cabin yang telah diproses di body shop. Proses pengerjaan cabin pada satu jalur yang sama, dengan waktu proses masing-masing model cabin yang berbeda. Oleh karena itu, dibutuhkan jadwal untuk pengambilan cabin yang akan diproses pertama kali pada departemenpaint shop (yaitu pada stasiun kerja preparation PTC), karena dengan tidak adanya jadwal yang pasti, maka akan berpotensi mengakibatkan stasiun kerja mengalami blocking, sehingga tidak mencapai target yang perusahaan inginkan. Gambar 5 menunjukkan influence diagram yang menggambarkan bahwa pada proses preparation PTC, diperlukan pengaturan urutan pengerjaan cabin, yang dapat dilihat pada simbol persegi panjang.

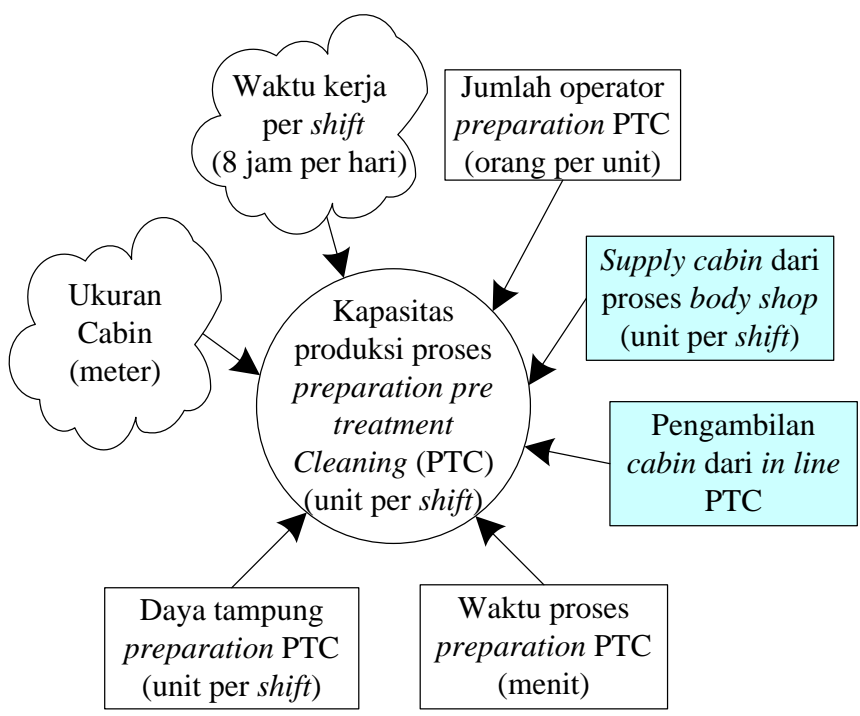

Gambar 5. Influence Diagram Proses Preparation PTC

Perusahaan mengatur pengambilan cabin untuk diproses pada stasiun PTC pertama kali secara fleksibel, maksudnya tidak terdapat pengaturan jadwal pengambilan cabin pada in line body shop (adalah antrian cabin dari hasil body shop) untuk diproses pertama kali pada stasiun kerja PTC. Usulan awal adalah penentuan perbandingan pengerjaan cabin sebesar $4: 1$, yaitu 4 pengerjaan 
cabin $\mathrm{N}$-Series dilakukan terlebih dahulu selanjutnya diikuti oleh $1 \mathrm{~F}$-Series dengan menggunakan perintah send pada model simulasi. Output yang dihasilkan simulasi komputer sebesar 40 unit $\mathrm{N}$ Series per shift dan 9 unit $F$-Series per shift. Namun, output yang diinginkan perusahaan adalah 43 unit $N$-Series per shift dan 11 unit $F$-Series per shift. Oleh karena itu, urutan pengerjaan cabin yang diutamakan yaitu model $F$-Series, agar kapasitas produksi yang diinginkan perusahaan tercapai. Usulan selanjutnya yaitu 1 pengerjaan cabin F-Series dilakukan terlebih dahulu selanjutnya diikuti oleh $4 \mathrm{~N}$-Series, dan hasil output simulasi komputer masih sama yaitu 40 unit $\mathrm{N}$-Series per shift dan 9 unit $F$-Series per shift.

Kebijakan pengaturan jadwal pada stasiun kerja preparation premer pun dibuat dengan mengutamakan pengerjaan cabin F-Series terlebih dahulu, dikarenakan pengerjaan cabin dari stasiun kerja sebelumnya yaitu check slide, fitting door, dan sealer menggunakan dua jalur yang terpisah antara model cabin $\mathrm{N}$-Series dan $\mathrm{F}$-Series. Waktu proses pengerjaan $\mathrm{F}$-Series relatif lama diabandingkan $\mathrm{N}$-Series pada stasiun kerja tersebut,dan kemudian akan masuk ke stasiun kerja preparation premer dengan satu jalur kembali, hal tersebut dapat mengakibatkan proses $N$-Series mendahului pengerjaan $F$-Series. Oleh karena itu, apabila cabin F-Series telah selesai dikerjakan, maka F-Series dikerjakan terlebih dahulu pada stasiun kerja preparation premer. Output yang dihasilkan pada simulasi komputer dengan menerapkan kebijakan ini sebesar 39 unit $N$-Series per shift dan 10 unit F-Series per shift. Hal tersebut sudah mencapai output F-Series yang lebih banyak, sehingga kebijakan ini dapat digunakan agar dapat mencapai output yang diinginkan perusahaan sebesar 43 unit $N$-Series per shift dan 11 unit F-Series per shift.

\subsubsection{Analisis dan Usulan Model Simulasi}

Tingkat kesibukan (utilisasi) operator touch up pada simulasi awal tinggi (dapat dilihat pada gambar 4), dimana utilisasi menunjukkan produktivitas dari semua faktor yang digunakan untuk menghasilkan output, sehingga tingkat kesibukan operator touch up yang tinggi ini berpotensi membuat target perusahaan tidak tercapai. Proses touch up merupakan proses akhir paint shop, dimana dilakukan general check proses painting untuk penaggulangan defect pada cabin yang dihasilkan dari seluruh proses paint shop sebelumnya. Proses touch up ini lama dikarenakan cabin yang dihasilkan banyak mengandung defect. Alternatif tindakan yang akan dilakukan sesuai dengan variabel keputusan yang telah dibuat pada influence diagram sebelumnya, dengan melihat variabel sistem kapasitas produksi touch up dipaparkan dalam Gambar 6.

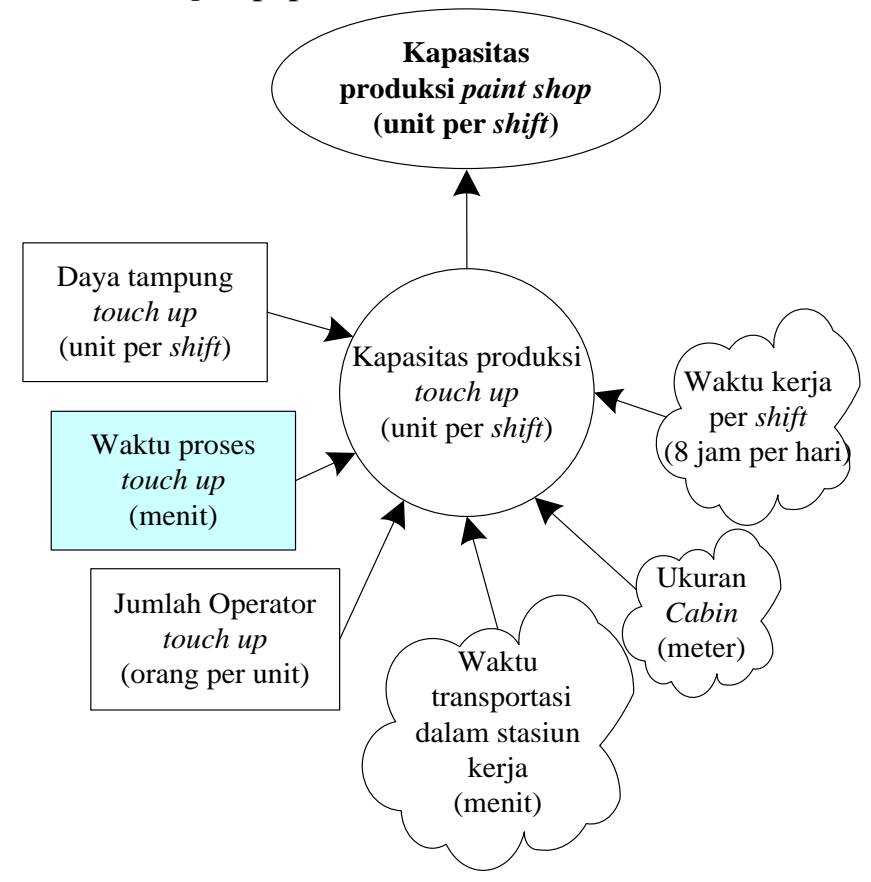

Gambar 6. Influence Diagram Proses Touch up 


\section{JOURNAL OF INTEGRATED SYSTEM VOL 1. NO. 1, JUNI 2018: 1-19}

Variabel keputusan untuk menghasilkan kapasitas produksi touch up, (baik dari segi kuantitas dan kualitas cabin yang dihasilkan) diantaranya menambah daya tampung touch up dengan menambahkan jumlah operator untuk mengerjakan proses ini. Namun, hal tersebut perlu mengeluarkan cost. Cara lain untuk menghasilkan kapasitas produksi touch up, yaitu dengan menekan waktu proses, karena pada kondisi di lapangan saat ini masih memungkinkan untuk menekan waktu di proses tersebut.

Berdasarkan hasil observasi dan wawancara dengan pihak perusahaan, pada bulan September 2014 terdapat defect pada cabin, meliputi popping, kotor atau flex, dan yellow metal. Defect kotor atau flex dihasilkan dari ketidak sesuaian area setting room, sedangkan defect popping dan yellow metal akibat ketidaksesuaian proses pengovenan, baik itu dari segi waktu proses pengovenan ataupun temperatur yang digunakan. Pengendalian defect ini perlu dilakukan, agar waktu proses di touch up dapat berkurang.

Pengendalian untuk defect kotor yaitu dengan memperhatikan area setting room. Area ini merupakan tempat penyimpanan cabin yang didalamnya tidak ada proses pengerjaan cabin yang dikerjakan oleh operator. Cabin hanya disimpan pada ruangan ini, dan akan terjadi proses flash off yaitu proses penguapan thinner. Oleh karena itu area setting room harus terbebas dari debu agar cabin yang dihasilkan tidak mengandung defect. Kebersihan area setting room harus dijaga, dinding dan lantai setting room harus bersih agar tidak menimbulkan debuUntuk membuat area setting room bersih, maka tindakan yang harus dilakukan adalah dengan membersihkan lantai dan dinding setiap hari sebelum kegiatan pabrik berlangsung. Awalnya pada area ini jarang dibersihkan, sehingga menyebabkan banyak debu disekitarnya, yang menjadi penyebab terjadinya defect kotor pada cabin. Berikut adalah tindakan yang dilakukan untuk menjaga area setting room terhindar dari debu:

- Jadwal Membersihkan Area Setting Room

Perusahaan tidak membuat jadwal khusus untuk membersihkan area setting room. Operator membersihkan ruangan ini setelah kegiatan operasi berjalan, dan pembersihan lantai hanya menggunakan sapu. Dinding setting room lebih jarang dibersihkan dibanding lantai, padahal dinding yang kotor pun dapat berpotensi menyebabkan defect pada cabin. Usulan jadwal untuk membersihkan area ini sangat dibutuhkan. Gambar 7 menunjukkan jadwal memulai membersihkan area setting room:

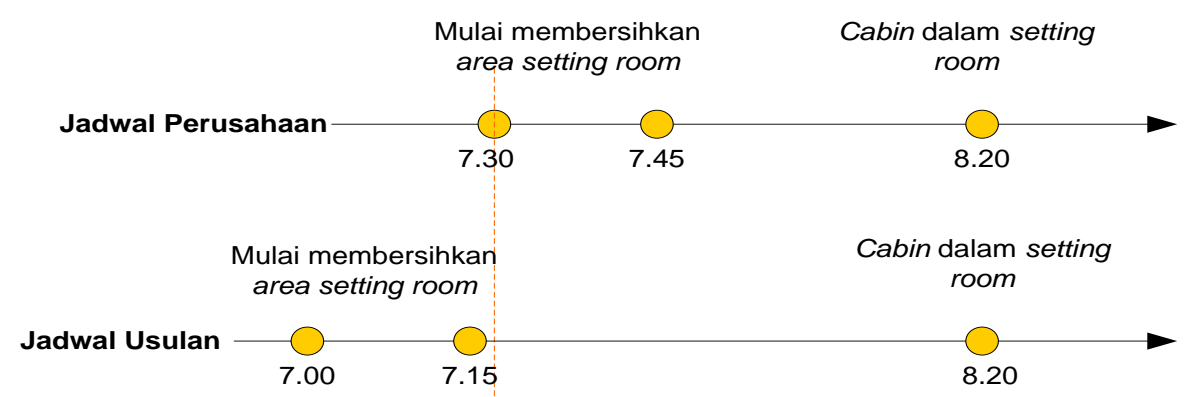

Gambar 7. Jadwal Memulai Kegiatan Pembersihan Setting Room

Pembersihan area setting room dilakukan pada saat waktu set up berlangsung, sehingga kebersihan area lebih terkontrol.Selain itu, membersihkan area setting room tidak dengan sembarangan, terdapat hal-hal yang harus dilakukan dalam membersihkannya. Berikut adalah cara membersihkan dinding dan lantai pada setting room:

1. Semprotkan air pada lantai setting room.

Cara ini lebih efektif dibandingkan hanya dengan menyapu lantai. Menyapu lantai mengakibatkan debu dapat berterbangan kemana saja. Namun dengan mensemprotkan air ke lantai, maka akan terbebas dari debu yang berterbangan. 


\section{PENINGKATAN KAPASITAS DENGAN MENINGKATKAN KINERJA LINI (Kirana H., dkk.)}

2. Pel lantai setting room dengan alat pel air.

3. Vakum lantai setting room.

4. Bersihkan dinding setting room dengan lap wash basin.

Lap wash basin mengandung zat kimia yang dapat mengangkat kotoran dengan mudah, sehingga wash basin digunakan untuk membersihkan dinding dari debu yang menempel.

5. Nyalakan blower settingroom.

Menyalakan blower sangat penting, karena dengan alat ini dapat menjaga keadaan ruangan. Kegunaan blower yaitu menghembuskan angin ke seluruh ruangan, sekaligus menyerap udara panas dengan menggantikan udara segar dari luar ruangan ke dalam ruangan yang telah melewati filter blower, sehingga membuat sirkulasi udara alami, segar, dan sehat.

- Kesesuaian Tekanan Udara Setting Room

Tekanan udara pada area setting room tidak boleh negatif (-), karena berpotensi menimbulkan defect pada cabin yang dihasilkan. Area setting room dilengkapi dengan exhaust fan dimana alat ini memiliki penyaring udara luar agar menghilangkan debu ketika udara masuk setting room. Penyaring exhaust ini harus selalu dibersihkan setiap satu jam sekali, karena bila penyaring kotor akan menyebabkan tekanan udara pada setting room negatif (-).

Pintu setting room sebaiknya selalu tertutup, namun keluar masuk cabin yang telah di spray melewati pintu setting room. Untuk melihat arah angin yang masuk antara spray booth dengan setting room, maka dibuat indikator berupa tali. Idealnya, udara yang masuk setting room tidak boleh terlalu banyak karena berpotensi membawa debu yang dapat mengakibatkan defect pada cabin. Sehingga arah indikator ini harus mengarah keluar pintu setting room agar menjaga tekanan udara dalam setting room stabil. Apabila arah angin lebih banyak masuk ke setting room, maka exhaust fan harus diatur kembali, dimana alat ini dilengkapi dengan pengaturan kecepatan angin sesuai dengan kebutuhan pabrik. Gambar 8 merupakan Indikator yang ada pada pintu setting room:

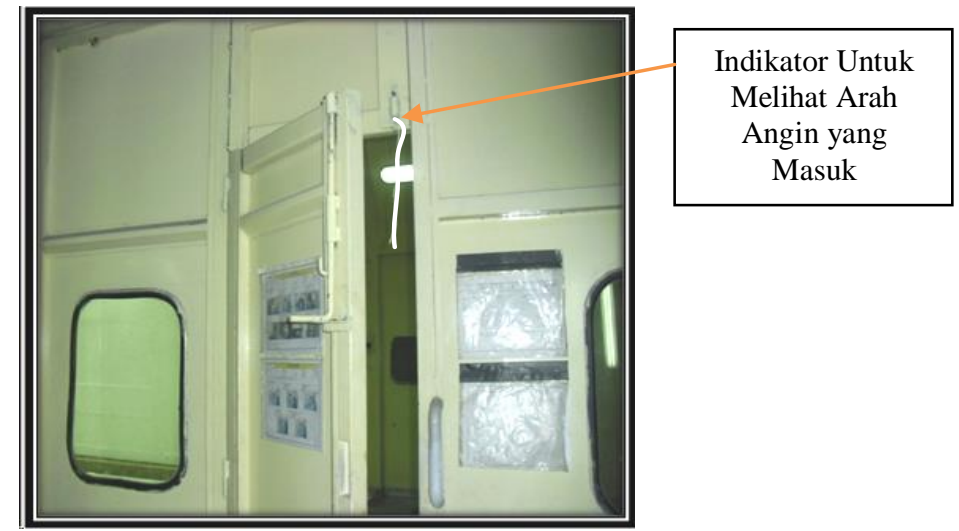

Gambar 8. Indikator Melihat Arah Angin

Pengendalian untuk defect popping dan yellow metal, yaitu dengan melihat kesesuaian proses pengovenan. Pengovenan sebagai alat pengeringan cabin dari proses sebelumnya merupakan proses yang sangat penting, karena kesesuaian pengovenan dapat menentukan kualitas cabin yang dihasilkan. Berikut adalah usulan untuk mengurangi defect yang ditimbulkan dari proses pengovenan:

- Alat bantu proses pengovenan

Jarak antara pemgovenan dengan stasiun kerja sebelumnya cukup jauh, misalnya pada stasiun kerja PTC, ukuran oven PTC adalah ( $5 \times 3$ ) m, jarak antara proses sebelum oven yaitu blow up 3 meter, dan bila operator yang bertugas mengeluarkan cabin dari oven, operator tersebut harus keluar dari pintu samping dan menuju pintu keluar oven dengan menempuh jarak 6 meter.

Gambar 9 menunjukkan jarak Oven PTC dengan proses sebelumnya. 
JOURNAL OF INTEGRATED SYSTEM VOL 1. NO. 1, JUNI 2018: 1-19

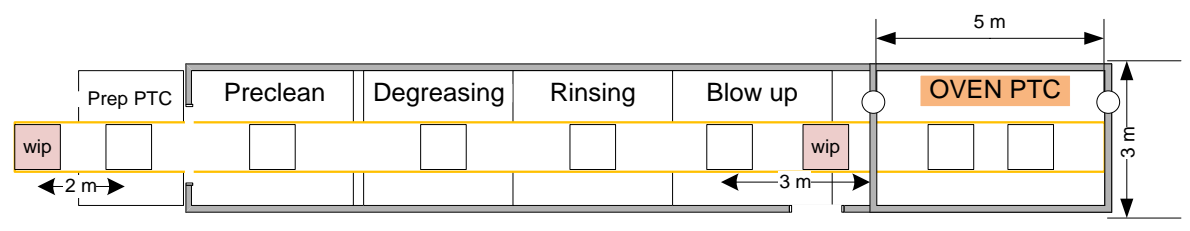

Gambar 9. Jarak Oven dengan Proses Sebelumnya

Operator membutuhkan waktu untuk membuka dan mengeluarkan cabin dari oven. Namun waktu pengovenan harus tepat, tidak boleh lebih lama ataupun kurang dari waktu standar yang telah ditetapkan. Bila hal itu terjadi, maka akan menimbulkan defect pada cabin yang dihasilkan. Saat ini, alat bantu untuk mengetahui proses pengovenan selesai hanya dengan jam dinding dan daftar cabin yang telah masuk dan keluar oven. Operator yang bertugas mengeluarkan cabin dari oven harus berkonsentrasi tinggi terhadap jadwal cabin yang harus dikeluarkan dari oven. Hal tersebut berpotensi menimbulkan human error pada operator yang mengakibatkan cabin mengalami defect. Untuk itu, usulan untuk membuat alat bantu dalam menentukan proses pengovenan selesai menjadi sangat penting. Alat bantu yang diusulkan berupa indikator lampu sebagai tanda proses pengovenan selesai. Terdapat 2 buah lampu yang masing-masing akan dipasang di daerah pintu buka dan tutup oven. Lampu akan berwarna merah apabila cabin sedang diproses, kemudian lampu akan berkedip 1 menit sebelum proses pengovenan selesai, dan lampu berubah menjadi hijau apabila cabin telah selesai dioven. Lampu indikator akan mati ketika operator membuka pintu oven. Pembuatan sensor lampu ini bertujuan untuk membantu operator dalam menentukan kapan operator harus bergegas menuju pintu keluar oven dan memasukan cabin selanjutnya agar proses pengovenan cabin tepat waktu, sehingga dapat memastikan kualitas cabin baik.

- Frekuensi pengaturan suhu ruang oven

Suhu pada ruang oven harus sesuai standar yang telah ditetapkan. Namun pengaturan temperatur masih bersifat manual. Suhu dalam ruang oven ini bisa tiba-tiba berubah menjadi lebih rendah, oleh karena itu operator harus selalu mengecek temperatur ketika akan memasukan cabin ke oven. Pengontrolan alat pengatur suhu oven setiap setengah jam sekali oleh operator yang bertugas memasukan dan mengeluarkan cabin pada oven. Hal ini dilakukan untuk menjaga suhu oven tetap sesuai standar yang telah ditentukan, sehingga dapat memastikan kualitas cabin yang dihasilkan terhindar dari defect.

Setelah defect dikendalikan,maka penekanan waktu proses touch up pada simulasi usulan pun dapat dilakukan. Namun, proses preparation pun sangat erat kaitannya dengan penanggulangan defect. Oleh karena itu, dengan melihat variabel keputusan dalam influence diagram pada Gambar 10, maka tindakan yang dilakukan adalah: 


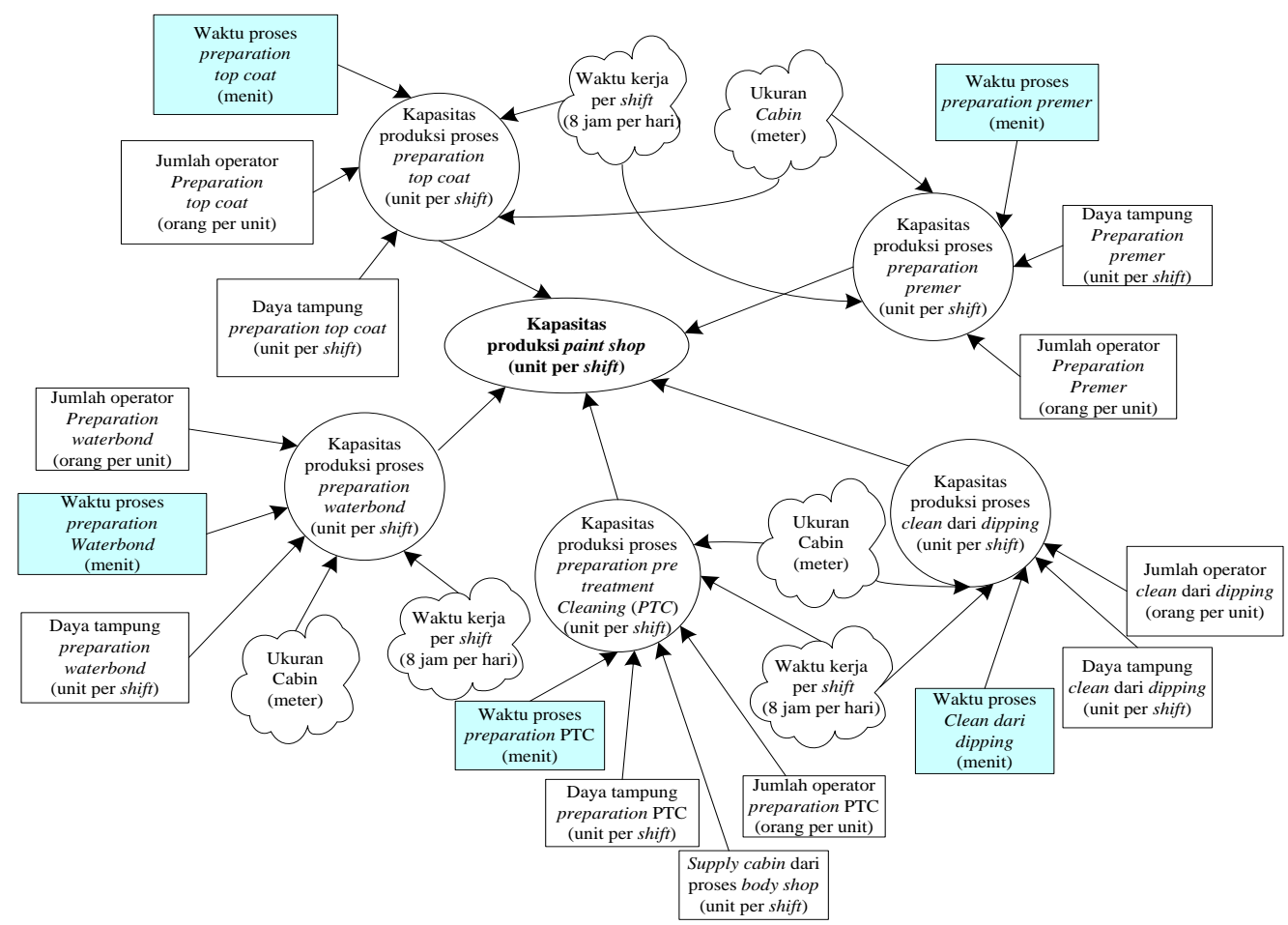

Gambar 10. Influence DiagramKapasitas Produksi Preparation

Penambahan waktu proses preparation dari data aktual perusahaan dilakukan pada simulasi usulan, dengan tujuan memberikan kelonggaran operator dalam bekerja, sehingga proses preparation dapat dilakukan dengan teliti dan tidak terburu-buru, dengan harapan defect dari setiap masing-masing proses menurun, sehingga berpengaruh terhadap penurunan waktu touch up diakhir proses paint shop. Waktu proses preparation ditambah 1 menit dari data awal proses $N$-Series, dengan tidak melakukan perubahan waktu proses di stasiun kerja lainnya. Proses preparation meliputi, preparation water bond, clean, preparation premer, wet and sanding (W/S) dan repair W/S, dan preparation top coat. Hasil output simulasi dari penambahan waktu preparation ini sebesar 40 unit $N$-Series per shift, dan 9 unit $F$-Series per shift, sehingga tidak ada perubahan yang signifikan dari output aktual perusahaan. Oleh karena itu, penambahan waktu preparation ini dapat dilakukan.Dengan tingkat kesibukan operator seperti pada Gambar 11.

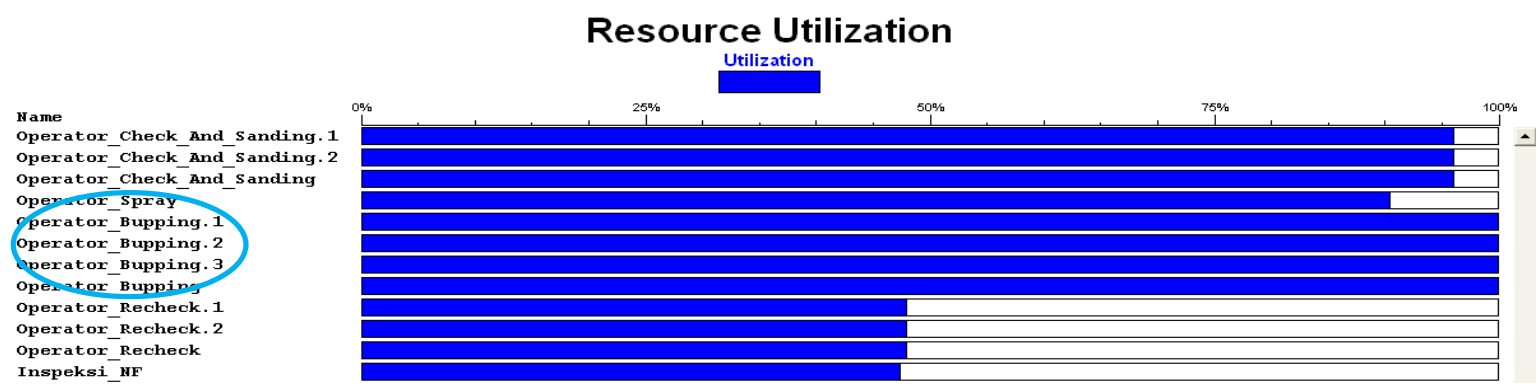

Gambar 11. Grafik Tingkat Kesibukan Operator dari Penambahan Waktu Preparation

Penekanan waktu proses bupping akan dilakukan dengan melihat tingkat kesibukan operator (Gambar 11), dari 10,2 menit menjadi 7 menit, sesuai dengan waktu siklus untuk model $N$-Series yang telah perusahaan tetapkan. Penekanan hanya pada model $N$-Series dikarenakan waktu proses bupping model ini melebihi waktu siklus yang perusahaan tetapkan.Hasil output dari penekanan waktu buppingdilihat dari hasil simulasi adalah sebesar 41 unit $\mathrm{N}$-Series per shift, dan 10 unit $\mathrm{F}$ Series per shift. Dapat dilihat dari tabel 2 dibawah ini pada kolom total exits yang dihasilkan. 
JOURNAL OF INTEGRATED SYSTEM VOL 1. NO. 1, JUNI 2018: 1-19

Tabel 2. Output Simulasi dari Penekanan Bupping

\begin{tabular}{|l|r|r|r|r|r|}
\hline Name & Total Exits & Current Qty In System & Avg Time In System (MIN) & Avg Time In Move Logic (MIN) & Avg Time Waiting (MIN) \\
\hline Cabin NS atas & 41,00 & 34,00 & 577,93 & 18,03 \\
\hline Cabin FS atas & 10,00 & 11,00 & 703,07 & 21,62
\end{tabular}

Output yang dihasilkan masih belum mencapai target perusahaan sebesar 43 unit $\mathrm{N}$-Series per shift, dan 11 unit F-Series per shift. Analisis tingkat kesibukan operator yang baru ditunjukkan pada Gambar 12.

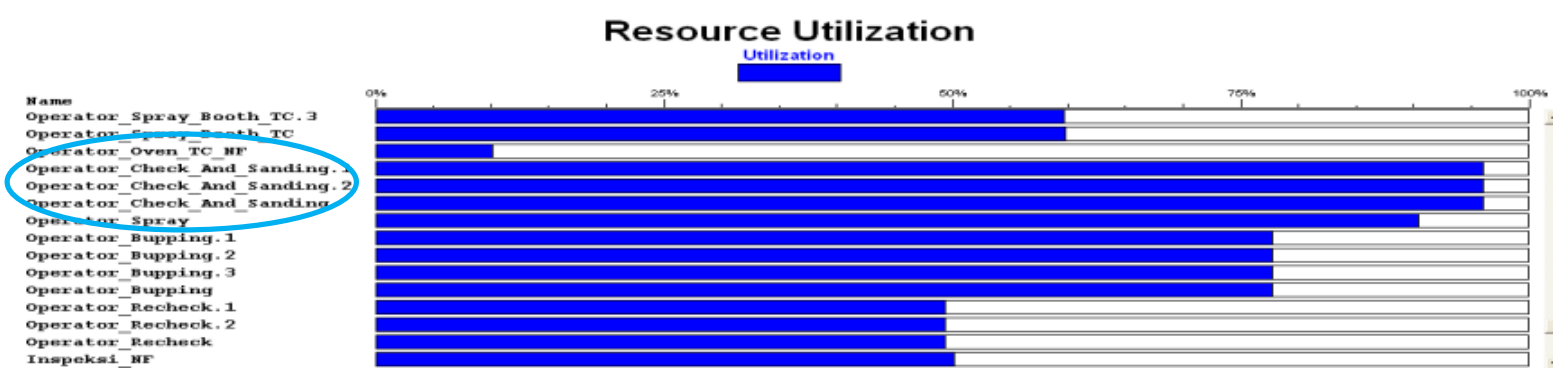

Gambar 12. Grafik Tingkat Kesibukan Operator dari Penekanan Waktu Bupping

Dengan melihat grafik pada Gambar 12, tingkat kesibukan operator pada proses check and sanding tinggi, maka selanjutnya dilakukan kembali penekanan waktu pada proses check and sanding dari 9,8 menit menjadi 7 menit.

Tabel 3. Output Simulasi dari Penekanan Check and Sanding

\begin{tabular}{|l|r|r|r|r|} 
Name & Total Exits & Current Qty In System & Avg Time In System (MIN) & Avg Time In Move Logic (MIN) \\
\hline Cabin NS atas & 41,00 & 35,00 & 565,10 & 17,94 \\
\hline Cabin FS atas & 10,00 & 14,00 & 743,90 & 21,46
\end{tabular}

Output yang dihasilkan dari penekanan proses check and sanding (dapat dilihat pada kolom total exits) adalah 41 unit $N$-Series per shift, dan 10 unit F-Series per shift. Hasil output masih belum mencapai target perusahaan, dengan tingkat kesibukan operator menjadi seperti pada Gambar 13.

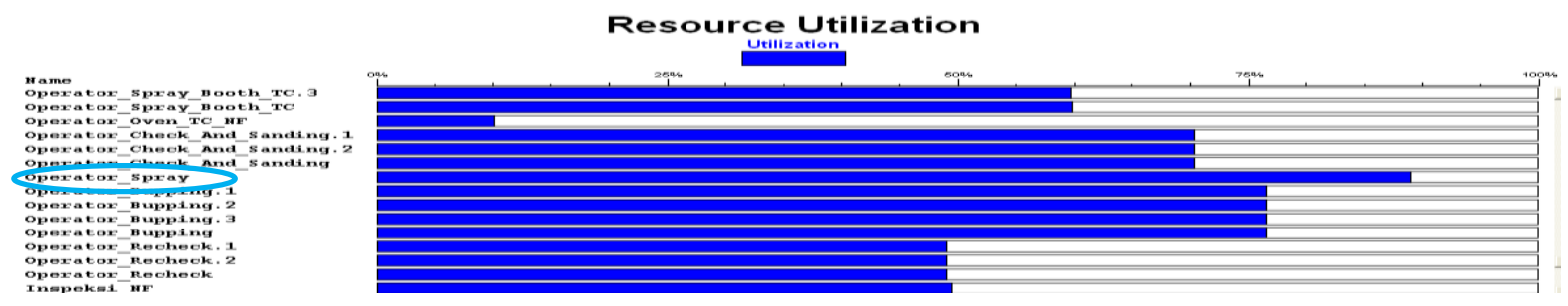

Gambar 13. Grafik Tingkat Kesibukan Operator dari Penekanan Waktu Check and Sanding

Tingkat kesibukan operator, proses spray memiliki uitilisasi yang tinggi. Oleh karena itu dilakukan kembali penekanan waktu proses pada spray menjadi 7 menit. Hasil dari penekanan waktu proses spray ditunjukkan pada Tabel 4. 
PENINGKATAN KAPASITAS DENGAN MENINGKATKAN KINERJA LINI (Kirana H., dkk.)

Tabel 4. Output Simulasi dari Penekanan Spray

\begin{tabular}{|l|r|r|r|r|r|r|r|} 
Name & Total Exits & Current Qty In System & Avg Time In System (MIN) & Avg Time In Move Logic (MIN) & Avg Time Waiting (MIN) & Avg Time In Operation (MIN) & Avg Time Blocked (MIN) \\
\hline Cabin NS atas & 43,00 & 27,00 & 538,82 & 17,93 & 190,60 & 257,08 \\
\hline Cabin FS atas & 11,00 & 10,00 & 679,83 & 18,84 & 247,06 & 73,20
\end{tabular}

Dengan melihat output yang dihasilkan dari simulasi komputer (dapat dilihat pada kolom total exits tabel 4), peningkatan kapasitas produksi paint shop sudah tercapai. Hasil output perusahaan awalnya hanya 40 unit $N$-Series per shift, dan 9 unit $F$-Series per shift, sekarang menjadi 43 unit $N$ Series per shift, dan 11 unit F-Series per shift. Hal tersebut sudah sesuai dengan target yang diinginkan perusahaan, dengan tingat kesibukan operator tidak ada yang melebihi $90 \%$, sehingga sudah dalam batas normal operator bekerja. Grafik pada Gambar 14 merupakan tingkat kesibukan operator pada masing-masing proses.

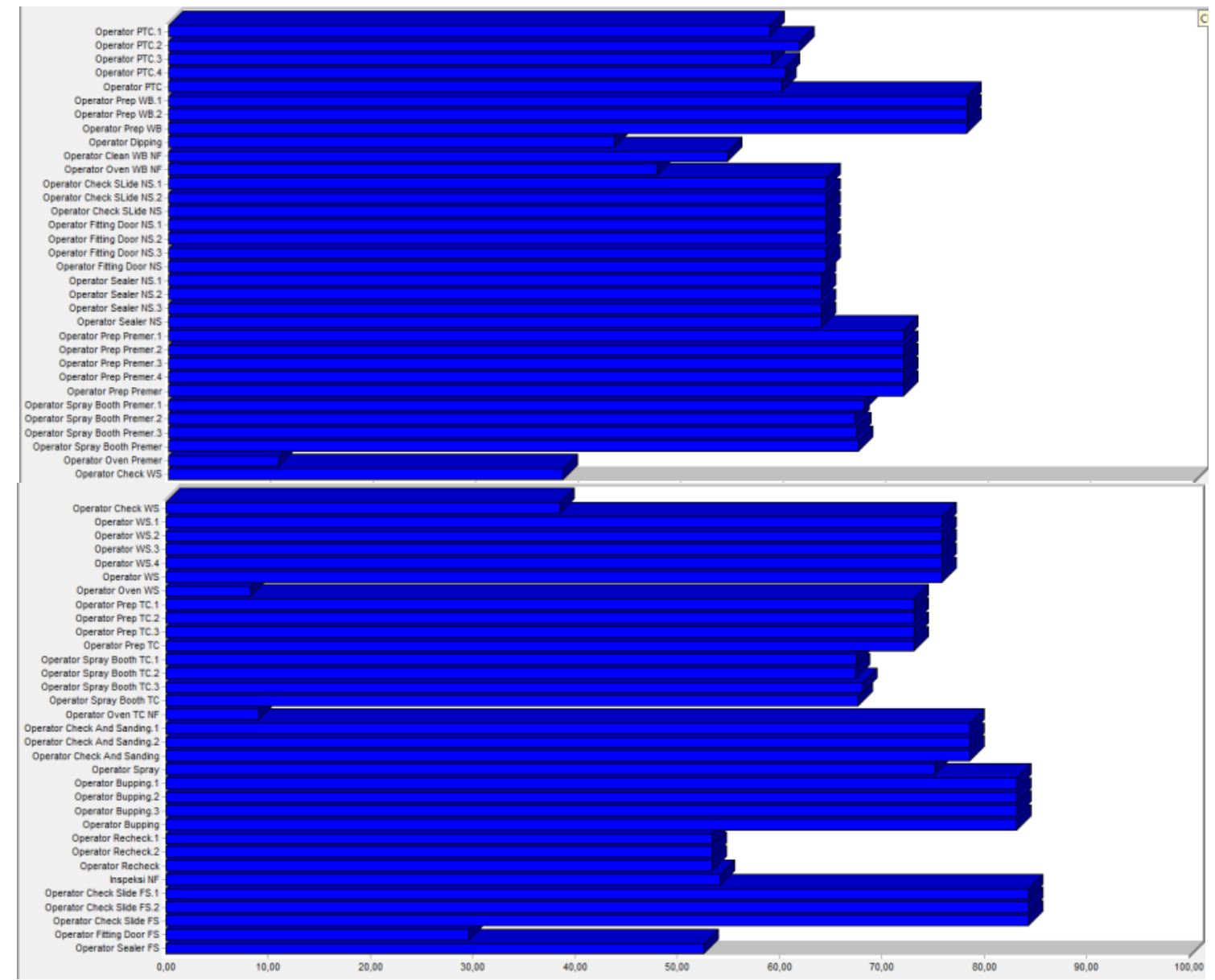

Gambar 14. Grafik Tingkat Kesibukan Operator Paint Shop

\section{Kesimpulan dan Saran}

\subsection{Kesimpulan}

Berdasarkan hasil pengolahan data dan analisis, dapat disimpulkan bahwa:

1. Usulan Urutan Jadwal Pengerjaan Cabin

Urutan jadwal pengerjaan cabin pada stasiun kerja pertama departemen paint shop harus diatur untuk menghindari blocking. Urutan jadwal pengerjaan cabin mengutamakan pada model $F$ Series, dengan perbandingan $1: 4$, yaitu 1 pengerjaan cabin F-Series dilakukan terlebih dahulu, selanjutnya diikuti oleh $4 \mathrm{~N}$-Series. Selain itu, kebijakan pengaturan jadwal pada stasiun kerja 


\section{JOURNAL OF INTEGRATED SYSTEM VOL 1. NO. 1, JUNI 2018: 1-19}

preparation premer pun dibuat dengan mengutamakan pengerjaan cabin F-Series terlebih dahulu,dikarenakan pengerjaan cabin dari stasiun kerja sebelumnya yaitu check slide, fitting door, dan sealer menggunakan dua jalur yang terpisah antara model cabin $\mathrm{N}$-Series dan $\mathrm{F}$ Series yang selanjutnya masuk pada stasiun kerja preparation premer di satu jalur yang sama, hal ini dapat mengakibatkan proses $\mathrm{N}$-Series mendahului pengerjaan $\mathrm{F}$-Series.

2. Usulan Pencapaian Output yang Diiginkan Perusahaan

Alternatif tindakan yang dilakukan untuk pencapaian output perusahaan sebesar 43 unit $\mathrm{N}$ Series per shift dan11 unit F-Series per shift adalah dengan menekan waktu touch up. Namun, sebelum melakukan penekanan waktu touch up, terlebih dahulu melakukan pengendalian defect yang terjadi pada cabin, karena proses touch up ini merupakan proses akhir pada painting untuk menanggulangi defect yang dihasilkan dari seluruh proses paint shop sebelumnya. Pengendalian defect antara lain dengan memperhatikan kesesuaian area setting room serta ketepatan waktu dan temperatur yang digunakan pada proses pengovenan. Selain itu, penambahan waktu proses preparation selama 1 menit dari data aktual perusahaan dilakukan, dengan tujuan agar proses preparation dapat dilakukan dengan teliti dan tidak terburu-buru, dengan harapan defect dari setiap masing-masing stasiun kerja menurun, sehingga mempengaruhi penurunan waktu touch up diakhir proses paint shop.

Penekanan waktu proses touch up dilakukan menggunakan simulasi komputer dengan mengatur jadwal urutan pengerjaan cabin,kemudian melihat peningkatan output serta menganalisis tingkat kesibukan operator. Proses bupping pertama kali ditekan dari 10,2 menit menjadi 7 menit karena tingkat kesibukan operator yang mencapai $100 \%$. Kemudian waktu proses check and sanding dari 9,8 menit menjadi 7 menit, dan terakhir adalah spray dari 9,5 menit menjadi 7 menit. Penekanan waktu proses disesuaikan dengan waktu siklus pengerjaan $\mathrm{N}$-Series yang telah ditetapkan perusahaan. Setelah memperbaiki performansi setiap stasiun kerja, dan melakukan tindakan berdasarkan pemilihan variabel keputusan yang diterapkan pada pembuatan simulasi usulan, maka output yang dihasilkan mencapai 43 unit $\mathrm{N}$-Series per shift, dan 11 unit $F$-Series per shift, yang awalnya hanya 40 unit $N$-Series per shift, dan 9 unit $F$-Series per shift. Hal tersebut telah sesuai dengan target yang perusahaan inginkan.

\subsection{Saran}

1. Saran untuk Perusahaan

Saran yang diberikan adalah pembuatan jadwal pengambilan cabin yang akan diproses pada stasiun kerja pertama, yaitu PTC dengan perbandingan 1 F-Series dikerjakan terlebih dahulu kemudian $4 \mathrm{~N}$-Series. Apabila usulan ini diterapkan, maka perlu diperhatikan untuk departemen sebelum paint shop agar selalu tepat waktu dalam menyelesaikan pengerjaan cabin, karena akan berpengaruh terhadap proses painting. Selain itu penekanan waktu proses produksi harus memperhatikan sumber kendala yang menjadi penyebab tinggginya waktu proses tersebut.

2. Saran untuk Penelitian Selanjutnya

- Memberikan improvement proses preparationpaint shop agar meminimasi terjadinya defect yang dihasilkan dari masing-masing stasiun kerja.

- Kembangkan model probabilistik untuk mengakomodasi perilaku sistem yang ada pada permasalahan peningkatan kinerja lini produksi paint shop, sehingga data yang diambil distribusi statistiknya dapat lebih mewakili kondisi yang riil. 
PENINGKATAN KAPASITAS DENGAN MENINGKATKAN KINERJA LINI (Kirana H., dkk.)

\section{Daftar Pustaka}

Daellenbach, H. G. (1991), System and Decision Making a Management Science Approach.Chichester : John \& sons Ltd.

Harrell, C., Ghosh, B.K., Bowden, R.O. (2003), Simulation Using ProModel 2/e The McGraw-Hill, International Edition.

Heshmat, M., El-Sharief, M. A., El-Sebaie, M. G. (2013), Simulation Modeling of Production Lines: A Case Study of Cement Production Line. Journal of Engineering Sciences, Assiut University.

Hafezalkotob, A. Ketabian, H., Rahimi, H. (2014), Balancing the Production Line by the Simulation and Statistics Techniques: A Case Study.Research Journal of Applied Sciences, Engineering and Technology.

Khalafi, S., Raissi, S. (2014), Industrial Valves Production Line Bottleneck Analysis: A Computer Based Simulation Approach. International Journal of Scientific \& Technology Research Volume 3.

Law. A. W., Kelton, W. D. (1991), Simulation Modeling And Analysis Second Edition, McGraw Hill, International Edition.

Papadopoulos, C. T., O’Kelly, M. E. J., Vidalis, M. J., Spinellis, D. (2009), Analysis and Design of Discrete Part Production Lines. Springer.

Saidabad, A. A., Taghizadeh, H. (2015), Performance and Improvement of Production Line Function using Computer Simulation (Cast Study: An Iron Foundry). American Journal of Computational Mathematics.

Simatupang, T. M. (1995), Pemodelan Sistem. Klaten: Penerbit Nindita.

Wirabhuana, A., Haron, H., Imtihan, M. R. (2008), Simulation and Re-engineering of Truck Assembly Line. Second Asia International Conference on Modelling \& Simulation. 